\title{
MULTIPLE CRITERIA DECISION SUPPORT SYSTEM FOR THE ASSESSMENT OF ENERGY GENERATION TECHNOLOGIES CONSIDERING THE DIMENSION OF VALUES
}

\author{
Jūratė ŠLIOGERIENE் $1 \bowtie$, Artūras KAKLAUSKAS ${ }^{2}$, Dalia S̆TREIMIKIENE் 3 \\ and Massimo BIANCHI ${ }^{4}$ \\ ${ }^{1}$ Laboratory of Energy Systems Research, Lithuanian Energy Institute, Breslaujos g. 3, \\ LT-44403 Kaunas, Lithuania and Department of Construction Economics and Property \\ Management, Vilnius Gediminas Technical University, Sauletekio al. 11, LT-10223 Vilnius, \\ Lithuania \\ E-mail: jurate.sliogeriene@vgtu.lt \\ ${ }^{2}$ Department of Construction Economics and Property Management, Vilnius Gediminas \\ Technical University, Sauletekio al. 11, LT-10223 Vilnius, Lithuania \\ ${ }^{3}$ Laboratory of Energy Systems Research, Lithuanian Energy Institute, Breslaujos g. 3, \\ LT-44403 Kaunas, Lithuania \\ ${ }^{4}$ Department of Managerial Sciences, Bologna University, Piazzale della Vittoria, 14-47100 \\ Forli, Italy
}

Received 7 November 2011; accepted 9 March 2012

\begin{abstract}
Comprehension of the effect of energy generation technologies on the natural environment, human health and safety leads to a new and responsible approach to the choice and development of technologies. When it comes to preparing energy growth scenarios and handling issues related to the choice and assessment of technologies, environmental studies must be in a particular spotlight. One way to make quantitative and qualitative assessment of the effect of technologies on the environment is through a thorough integrated analysis, which, in addition to economic and technical solutions, also considers other aspects of concern to the public. A changed environment demands for systems of criteria which help consider its changes, the attitudes of the general public, public sentiments toward the effect of technologies, public values and community involvement in the process of important decision-making. The article examines how the dimension of values affects the analysis of the impact of environmental factors on the value of energy generation technologies. It presents a set of criteria for the assessment of energy generation technologies; the set, in addition to technological, economic and environmental criteria, includes criteria which reflect the values. The article also introduces the expert decision support system EGTAV-SPS, which helped assess the effect of environment on energy production technologies.
\end{abstract}

KEYWORDS: Criteria of social issues and values; Multiple criteria analysis; Energy generation technologies; Energy-sector culture; Ethics; Decision support system

\section{INTRODUCTION}

Usually the technical systems is evaluated using only technical and economical criteria. But estimation of these criteria is not adequate enough. In attempts to find the best solutions to satisfy growing energy demands and ensure reliable supply, increasingly prevalent is the idea that technological parameters and economic efficiency are not crucial to guar-

Copyright (C) 2012 Vilnius Gediminas Technical University (VGTU) Press Technika 
antee welfare. Life cycle of energy system is much longer than period of reliable economical prognosis (Rogoža et al., 2006). The most relevant issue in today's energy development is selection of the technologies which are the best for people, rather than the most efficient. Operation and growth of energy systems is very closely related to public needs, security and welfare, hence they cannot be viewed without consideration of relevant important aspects.

Planning the course of energy-sector growth or handling issues related to the choice of energy generation technologies means assessment of loads of technical, economic, social and other information-contradictory at times. It is important to use relevant sets of criteria, which describe in detail the environment being analysed; one must also be aware of the effect of criteria and obtain helpful information for preparation of solutions. The indicators for sustainable energy development formulated by the International Atomic Energy Agency, EUROSTAT and the United Nations help evaluate the sustainability of national energy sector, compare it between countries by separate indicators, assess the trends of sustainable energy development and take appropriate actions which shift or promote these trends (International Atomic Energy... 2005). A number of systems of criteria have been developed and are used to assess sustainability and growth of energy sector in individual countries, with a view to national priorities and aspects relevant to the growth (Sovacool and Mukherjee, 2011; Štreimikienè et al., 2007; Vera and Langlois, 2007). Such sets of criteria define economic, environmental protection and social dimensions of energy generation technologies. In the said systems of criteria, the social dimension usually omits the criteria of values. But values-culture, cultural identity, ethics, beliefs, religion, education, weight of social institutes and other-can make an important impact on decisions related to the development of energy generation technologies, or even be the deter- mining factor. Growing significance of public attitudes demands consideration of the dimension of values in environmental studies; when problems concern technologies they must also consider the values which are important and significant to the public or its separate groups.

The article reviews academic research papers which discuss the role of values in the energy sector (Chapter 2) and then presents a set of criteria for the assessment of the environment of energy generation technologies with emphasis on the dimension of social issues and values (Chapter 3). Then, the effect of environmental factors on the value of energy generation technologies is examined using the set of criteria augmented with the dimension of values and the decision support system EGTAV-SPS based on multiple criteria analysis. The decision support system makes integrated analysis of the factors which describe quantitative and qualitative aspects of the technologies in question (economic, technical and environmental protection factors, as well as the factor of social issues and values), assesses the effect of individual criteria and recommends ways to improve them (Chapter 4). The article ends with conclusions (Chapter 5).

\section{DIMENSION OF SOCIAL ISSUES AND VALUES IN ENERGY SECTOR}

The role of values came into focus not by accident. The dimension of values and analysis of cultural, ethical and psychological specifics and differences is increasingly dominant when it comes to relationship-building at various levels (Vallance et al., 2011). In general, values may be perceived as desirable principles of action, goals and wealth-generating factors present in society or a certain societal group. At the same time, values determine the limits observed in the pursuit of goals. The substance of the concept of values may be construed as the perception about the desirable state of some system and deliberately chosen rules of 
coexistence (Williams, 1979; Schwartz, 1996). Acknowledging the fact that values are a fundamental concept in any system, it should be noted that economic and technological factors dominate in any decision on development or choice of technologies. A. Kemmler and D. Spreng noticed that "the use of energy indicators is not restricted to environmental and economic issue but is also relevant for social issues" (Kemmler and Spreng, 2007, p. 2466).

The United Nations General Assembly has recognised the importance of human values to achieve sustainable development and declared certain fundamental values to be essential to international relations in the twenty-first century. The declaration lists values such as solidarity, tolerance, equality, respect for nature, and shared responsibility (UN, 2000, p. 6). Despite their importance, little is known about the nature of sustainability values and much work needs to be done in developing such scales (Shepherd et al., 2009).

Although the importance of the dimension of values is fully comprehended, academic literature examining the environment of energy sector and issues of sustainable development has never presented a through analysis of relationships between "values" and energy. The authors reviewed the academic literature from the past five years containing such keywords as energy technologies and value, energy and ethics, energy and psychology, energy culture, energy security, value criterion, cultural aspects in energy sector, value and sustainable energy development, etc. Another goal was to review papers analysing aspects of values in the context of sustainable energy development. It can be noted that measurable criteria, which describe economic, environmental-protection or social environment, have been thoroughly described in a range of publications. Assessment of the social aspect is usually suggested through measurable economic and demographic criteria without any consideration of the criteria of values. Criteria of values have not been systematically analysed, nor have been described any integrated studies examining the role of values in the development of energy projects. Academic publications accentuate and analyse individual values significant to solutions concerning energy growth, but new and original academic research, resting on the value-based approach to the aspects of public importance, must be performed in the future (Becker, 2001; Leiserowitz et al., 2006; Loomis and Rosenberger, 2006). Though the dimension of values is relevant at all levels, this article analyses the criteria of values attributed to the social factor. Such analysis of social environment, supplemented with the criteria of values, looks into the social aspect in an integrated way, considers important public attitudes and gives them prominence in environmental studies.

Having summarised the studies examining the dimension of social issues and values in energy sector and considering the opinion of experts who took part in the study, the following criteria, which are important to the industry's environment and should be investigated when various solutions of energy growth are being prepared, can be distinguished: 1) energy security; 2) assessment of public opinion on energy growth; 3) energy culture and ethics; 4) creating equal opportunities to be employed and be responsible for decision-making; 5) the principles of corporate social responsibility in energy companies. These criteria are briefly discussed below.

1) Energy security. In their discussions of sustainable energy development, both policymakers and academic circles often use the concept of energy security, although this concept has never been precisely explained. The concept of security of energy is usually dealing with the supply side of the energy systems. Energy security can be expressed by long-term independence from foreign energy source. This indicator was applied for evaluation of autonomy of electricity generation in NEEDS project 
(NEEDS ... 2007). Energy security is chiefly understood as capacity to secure stable, accessible and economically non-discriminating supply of energy sources for industrial, production and transportation needs (Löschel et al., 2010).

Today the concept of security of energy supply is much more expanded and includes more aspects than prior definitions. Environmental issues have become a very important element limiting the reliability of energy (Augutis et al., 2011). Literature examines the concept of energy security from a number of aspects, including risks related to sufficient supply of imported primary energy sources, diversification and variety of energy generation technologies, and the ratio of exports/imports and demand/supply. Energy security has also been assessed considering the social impact of the development of energy generation technologies (Löschel et al., 2010; Jansen and Seebregts, 2010; Gallego Carrera and Mack, 2010). In their studies of the concept of energy security, B. Kruyt, D. P. Vuuren, H. J. M. Vries and H. Groenenberg, distinguished four defining dimensions: the availability, accessibility, affordability and acceptability of energy (Kruyt et al., 2009). These dimensions, which define the gist of this concept, are also related to the dimension of social issues and values. Depending on national political-economic and cultural specifics, the role of energy security may vary. Having surveyed expert opinions in different countries and analysed sets of criteria, which include "security and reliability of energy provision", "political stability and legitimacy", "social and individual risks" and "quality of life", D. Gallego Carrera and A. Mack have noticed some differences between expert opinions in various countries (Gallego Carrera and Mack, 2010). The differences probably rest on the difference of culture and values in these countries. In an integrated assessment, when the scale of social factors has been supplemented with the criterion "energy security", the envi- ronment of energy generation technologies or the effect of their development can be examined and assessed considering national and cultural specifics.

Security of energy supply is a complex field of scientific research based on modelling of economical processes, analysis of geopolitical situations, network reliability and resistance to disturbance energy analysis, statistical expertise in emergency situations and violations in energy systems, risk analysis, energy supply problems, technical, social, political and other consequences (Augutis et al., 2011).

The European Union (EU) is one of the most active developers of energy security assessment methods and assurance measures. Its initiatives expressed in the directives up to 2020 would lead to a significant reduction of EU energy dependence on import.

2) Public opinion. Research shows that the dimension of values, construed as expressed public opinions, affects the implementation success of various development projects. Energy policymakers and people who prepare development strategies must consider public opinions, because energy technologies are related to the safety of the public and its environment. Academic papers explicitly assert that the public must take part in debates and discussions on the choice of future energy scenarios, because the public wants "reliable" energy in the future, the choice of energy technologies is relevant to the public, and projects must be broadly discussed (Grunwald, 2011; Smith, 2004; Rayner, 2010). "What the public thinks about energy is important because public opinion is a major force influencing public policy on energy production and consumption" (Smith, 2004, p.169). Unfortunately, the usual practice in political and public life is often to introduce to the public the solutions which have already been chosen for implementation.

Worries about climate change and energy security, rather than public determination, were the main arguments that decided the 
development of nuclear energy technologies as the key source of electricity in such countries as Finland, France and the UK. Having analysed the discussions which took part in the public domain of these countries and involved market participants, the state and the civil society, T. Teravainen, M. Lehtonen and M. Martiskainen have distinguished three key reasoning strategies that dominated these discussions: 'technology-and-industry-knowbest' in Finland, 'government-knows-best' in France, and 'markets-know-best' in the UK. They reflect the attempts of stakeholder groups to find ways to reconcile the positions of the market, politics and civil society (Teravainen et al., 2011). But the wording of these strategies suggests that the public is not they key participant in the decision-making process. The importance of dialogue with the public has been proved by E. R. N. Smith with the help of this US example: "public opposition to nuclear power, especially after the 1979 Three Mile Island accident, helped block the construction of new nuclear power plants. In the aftermath of the accident, public support for nuclear power dropped sharply, and every proposal for a new nuclear facility was met with mass protests. Public opposition, coupled with soaring construction costs, ended the growth of the nuclear power industry. No more nuclear power plants were ever ordered" (Smith, 2004, p. 169). The decision by Germany's government on the national energy growth may be another example. In 2010 energy growth in Germany was still associated with nuclear energy. Despite the differences of natural environment, the disaster in Fukushima power plant made the German society take a U-turn in their opinion about the development of nuclear energy technologies. After extensive public and academic discussions, in which the public unambiguously said "no" to the development of nuclear technologies, the German government made a decision to associate the future with the development of renewable energy genera- tion technologies (Grunwald, 2011). Japanese, Swiss and Italian governments considered public opinions and made equivalent decisions (at a referendum in June 2011, as many as $94 \%$ of Italian voters that went to the polls voted against plans to expand nuclear energy). Obviously, the debates with the public, or organisations representing the public position, made a significant impact on the choice of new development strategies.

Interestingly, despite growing popularity of renewable energy technologies, the development of these technologies is also subjected to debates. For instance, emerging wind power sparked worries in the public domain about the negative aspects of wind farms: changes of the natural environment (new bird migration patterns), noise and deteriorated landscape. Studies are necessary to support or reject these arguments, with the results announced to the public. In Britain, for instance, the effect of wind farms on the value of real property was examined after the communities, in which wind farms were being developed, had expressed their concern. A thorough analysis, based on the hedonistic price model, of data from real property deals did not show any causal relationship linking the drop of property's market value with wind farms in the vicinity. Announcement of the research findings helps to ground discussions and change public attitudes (Sims et al., 2008).

Analysis of the effect of public opinion on the decision-making process highlights the role of informing the general public and transfer of scientific data. Mutually equal discussion and the best outcome are only possible when the public has sufficient knowledge. Growth of interdisciplinary scientific fields in energy sector would let the science play a more important role in strengthening the relationships linking the public, politics and business (Palm and Thollander, 2010). Motivated debates are a basis to integrate new energy generation technologies. Scientists and science policy- 
makers must hear the public opinion, try to understand it and respond to issues raised by the public (Rayner, 2010).

3) Energy culture and ethics. Energy culture is construed as a relation between energy technologies and the public, as a way of communication. Energy culture is a new concept, but it encompasses a great deal of aspects of public life, including educating public to conserve energy resources, environmental protection issues and confidence in decisions concerning energy sector. Search for more effective means of understanding, and attempts to encourage energy-conserving behaviour, requires a focus on the shaping of a specific energy culture (Stephenson et al., 2010). The concept of energy culture has been partly formulated to achieve higher energy-efficiency, improve understanding of the effect on the environment and change the habits of consumption. Energy culture is also an attempt to help energy generation and supply companies understand different consumer-behaviour models and better accommodate their tariff plans and products. Energy culture affects consumer perceptions of technologies and shapes their convictions and attitudes (Stephenson et al., 2010).

Analysis of the role of energy culture cannot ignore ethical issues related to the public behaviour, the public's relationship with the nature and technologies, and responsibility. C. Moeller, who analyses ethical issues and the evolution of ethical relationships in the society, asserted that the attention to ethics is not a passing whim but is the answer to the changes in our society: the technological revolution brought forward new issues of air and environment pollution; changed laws mandate equal opportunities. Handling of sensitive public issues is only possible when ethical norms are respected (Moeller, 1998). The dimension of ethics is important in all areas. Science and technology cannot be above ethics (Matson and Carasso, 1999). Lack of attention to ethical issues decreases the chance to achieve the goals of sustainable development in energy sectoraccessibility and reliability of energy generation technologies. The importance of the dimension of ethics is particularly highlighted in wake of disasters. The case of Chernobyl, for instance, revealed that disregard of ethical and moral norms (failure to provide timely information about the accident, the possible effect on health, the protection measures, the necessity to evacuate and the places of evacuation; using victims for biomedical studies; etc.) raised not only public distrust but also more painful outcomes (Melnov and Sarana, 2010).

4) Creating equal opportunities to be employed and be responsible for decision-making. Academic literature has also examined ways to ensure the principles of equal opportunities for men and women in energy companies. A. Carlsson-Kanyama, I. R. Julia and U. Rohr have performed a study and analysed the situation of gender quality in management of energy companies and the role of women as members of managerial bodies in preparing and making strategic decisions (Carlsson-Kanyamaa et al., 2010; Huse et al., 2009). The scientists noticed different work styles and decision-making methods of both sexes and a slightly different perception of risks. Having surveyed 464 large energy companies in Germany, Spain and Sweden, they stated that among the companies surveyed as many as 295 (64\%) had no women in their managerial bodies and only $5 \%$ of companies could be considered examples of gender equality ( $40 \%$ or more women in managerial bodies). "Interviews with energy companies confirmed current trends that gender equality efforts within decision-making in business are weak or non-existent" (CarlssonKanyamaa et al., 2010). The research findings suggest that male consumption and emissions of greenhouse gases. Women have been noticed to be keener to take risks than men, which in boards, at a certain degree, may affect the decision-making process. More active involvement, and more say, of women in manage- 
ment of energy companies and in investment decision-making may encourage more radical handling of climate change and environmental issues, more determination with innovative solutions and choice of renewable technologies (Carlsson-Kanyamaa et al., 2010). Analysis of membership in boards and supervisory bodies of Lithuanian energy companies, including academic institutions, performed in 2011, confirms the trends noticed by the aforementioned scientists, because women account for less than $10 \%$ of members in managerial bodies of Lithuanian energy companies, and none of the companies could be considered ensuring gender equality. "The main argument promoting women as board members from a business case is usually that diversity is important for corporate value creation and that women can add unique perspectives, experiences and work style compared with their male counterparts" (Carlsson-Kanyamaal et al., 2010, p. 4738).

5) The principles of corporate social responsibility. Economic development can be considered sustainable only if the investments not only have economic efficiency but also do not violate the ecological and social foundation of economics. But economic entities must also move away from the system which has profit maximisation as its main goal toward a system which achieves this goal within the limits of sustainability. In order to achieve responsible consumption and rational attitude towards development strategies, the dimensions of profits and social benefits must be combined (Husted and Salazar, 2006).

Although awareness of the influence of social factors is growing, economic factors generally play the key role in decision-making related to development. The issues related to the choice and development of technologies are usually "reduced" to the level of economically most rational decisions. Business often exerts pressure to stick to more conservative decisions-particularly if they have greater economic efficiency (Cappers and Goldman, 2010).
Even the model of sustainable development sets economic tasks as the main goal (Sychev, 2010). Some authors believe that economic goals are stressed and given prominence not only because of the traditional interpretation of market behaviour but also by institutions of business education, which, in their teaching process, over-stress the economic matters and profits as the main goal of business and the purpose of corporate activities. It determines corresponding behaviour of future executives and managers, which later is transferred on to organisations and respectively shapes operational strategies of such organisations, corporate culture and the relationship with the consumer (Ferraro et al., 2009; Ghoshal, 2005). Corporate culture and appropriate management systems can reinforce the connection between the dimension of social capital and the economic and cultural dimension (Chenhall et al., 2010). In order to achieve sustainable energy development, energy companies should apply the principles of social responsibility in their activities. This voluntary measure implemented by energy enterprises can ensure efficient public-private partnership in achieving sustainable development targets. The main sustainable energy development goals and indicators to monitor achievements of these goals are: 1) increase in energy efficiency and 2) use of renewable energy sources (Štreimikienè et al., 2009).

Management strategies and policies directed towards economic efficiency of expenditures in research and development with human capital knowledge and investments into technologically intensive export- oriented products are significant for long-term sustainable economic development (Bojnec and Papler, 2011).

Hence, despite the importance of economic goals and technological advances, increasing attention is paid to the dimension of values: ensured opportunities to discuss and express opinions, respected culture, ethics and the principles of trust and equality. Social evolu- 
tion follows the laws of sociology, thus social issues and the issues of values must be centrestage when questions concern development and the assessment of technologies. Social aspects and acceptability of new technologies is a new alternative of energy policy (Becker, 2001; Schweizer-Ries, 2008; Musango and Brent, 2011).

\section{INFORMATION MODEL FOR THE ASSESSMENT OF THE ENVIRONMENT OF ENERGY GENERATION TECHNOLOGIES}

Handling of issues related to the choice and assessment of energy generation technologies includes analysis of highly diverse information - from economic and technological to social and value-related to the needs and impact of stakeholder groups. In order to select the most relevant information that describes alternatives, the research scope must be determined: 1) the environmental factors most relevant to the analysis distinguished; 2) quantitative and qualitative criteria that best describe the alternatives in question determined; 3 ) the set of criteria for the decision support system built; 4) select the most appropriate multicriteria method. Because a set of measurable criteria is insufficient to make a thorough analysis of the effect of environment considering the principles of sustainable development and public expectations, properly adapted sets of criteria are needed for the assessment of technologies. Any alternatives may be described using the information model in Figure 1, which combines technical, technological, economic and political information related to the environment and the dimension of social issues and values, but also allows describing the effect of the environment on the value of technologies.

The information needed for decision-making consists of quantitative and qualitative criteria. When the sets include qualitative criteria, the system can be more flexible in the integrated analysis of changing environment and can assess the role of the dimension of social issues and values. Some criteria, such as the profit margin and the risk of accidents, may be expressed both by quantitative and qualitative criteria.

The information needed for decision-making consists of quantitative and qualitative criteria. When the sets include qualitative criteria, the system can be more flexible in the integrated analysis of changing environment and can assess the role of the dimension of social issues and values. Some criteria, such as the profit margin and the risk of accidents, may be expressed both by quantitative and qualitative criteria.

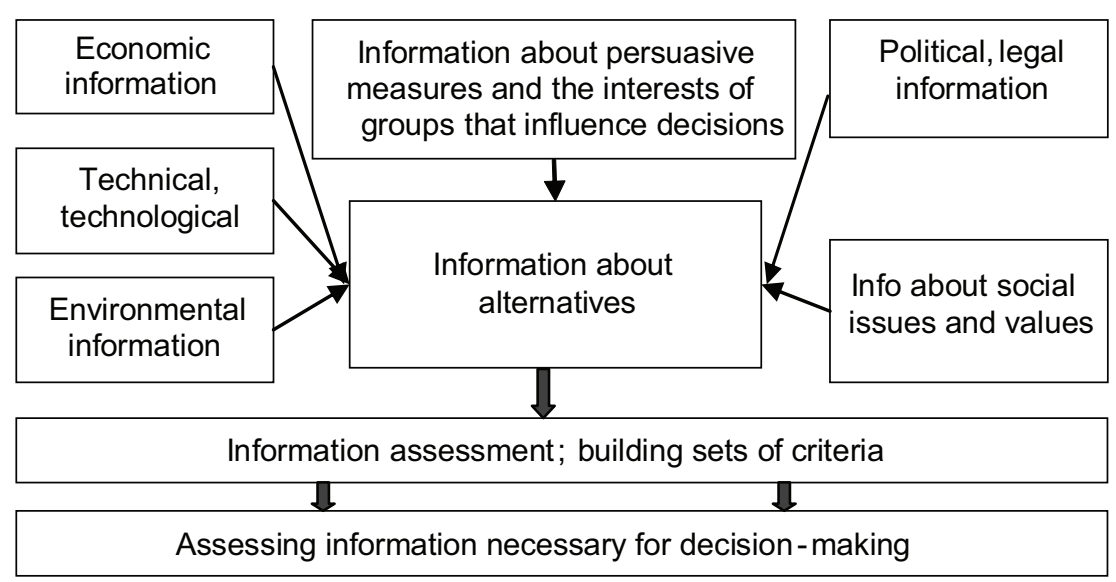

Figure 1. The information model for preparation of decisions 
The number of criteria in the sets depends on the research scope. In the decision support system, the selected quantitative criteria are expressed by relevant measuring units; qualitative criteria are scored by points determined through expert methods. An example of a set of criteria, supplemented with the criteria characterizing the aspect of values, is shown in Table 1.

Such large amounts of often contradictory information are best processed using multiple criteria evaluation methods and integrated software applications. Multiple criteria decision-making methods help compare and assess technologies, development scenarios, political measures and their efficiency. An advantage is the possibility to combine both quantitative and qualitative criteria in an integrated manner and to assess the relevant aspect from the entire pool of information. It can be meaningful to apply more than one method or combination of methods in order to reach a broader decision basis. Application of more than one method can provide decision makers different perspectives and an opportunity to compare results so that a more appropriate final decision can be made (Atici and Ulucan, 2011).

Analysis of the environment of energy generation technologies using multiple criteria analysis facilitates thorough examination of trends and the effect of environment, while comparison and ranking of technologies helps choose the most appropriate technologies and incorporate them into energy models.

Table 1. Assessment criteria of energy generation technologies

\begin{tabular}{|c|c|c|c|}
\hline & Aspect & Criteria & Unit \\
\hline \multirow{3}{*}{ 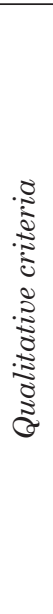 } & Political, legal & $\begin{array}{l}\text { Legal regulation of activities } \\
\text { Impact on energy security }\end{array}$ & $\begin{array}{l}\text { points } \\
\text { points }\end{array}$ \\
\hline & $\begin{array}{l}\text { Social issues } \\
\text { and values }\end{array}$ & $\begin{array}{l}\text { Accessibility of energy sources } \\
\text { Competitiveness of technologies } \\
\text { Dependence on resource provision } \\
\text { Profit margin } \\
\text { Energy culture and ethics } \\
\text { Equal employment opportunities } \\
\text { Collaboration with academic and research institutions } \\
\text { Influence on social environment } \\
\text { Innovativeness of the technology } \\
\text { Public attitude toward the technology } \\
\text { Application of social responsibility principles }\end{array}$ & $\begin{array}{l}\text { points } \\
\text { points } \\
\text { points } \\
\text { points } \\
\text { points } \\
\text { points } \\
\text { points } \\
\text { points } \\
\text { points } \\
\text { points } \\
\text { points }\end{array}$ \\
\hline & $\begin{array}{l}\text { Environmental } \\
\text { protection }\end{array}$ & $\begin{array}{l}\text { Reliability of the technology (risk of accidents) } \\
\text { Contribution to the share of renewable energy resources (RER) } \\
\text { in the total balance } \\
\text { Effect on climate change and pollution cuts }\end{array}$ & $\begin{array}{l}\text { points } \\
\text { points } \\
\text { points }\end{array}$ \\
\hline \multirow{3}{*}{ 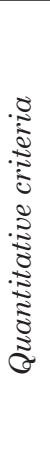 } & Economic & $\begin{array}{l}\text { Energy intensity in GDP terms } \\
\text { Energy generation technologies, the plant value (creation } \\
\text { costs) } \\
\text { Energy generation technologies, value of integrated } \\
\text { exploitation } \\
\text { Product cost (production price of energy) }\end{array}$ & $\begin{array}{l}\text { tne / €m } \\
€ \\
€ \\
€ \text { cents }\end{array}$ \\
\hline & $\begin{array}{l}\text { Environmental } \\
\text { protection }\end{array}$ & $\begin{array}{l}\text { Share of RER in final energy output } \\
\text { Greenhouse gas emissions } \\
\text { Traditional emissions: SO2, NOx, CO } \\
\text { Energy consumption intensity by GDP } \\
\text { Pollution taxes }\end{array}$ & $\begin{array}{l}\% \\
' 000 \text { tonnes } \\
' 000 \text { tonnes } \\
(\mathrm{TNE}) / € \mathrm{€m} \text { of GDP } \\
€ \mathrm{~m}\end{array}$ \\
\hline & Technical & $\begin{array}{l}\text { Rated capacity } \\
\text { Risk of accidents }\end{array}$ & $\begin{array}{l}\text { MW } \\
\%\end{array}$ \\
\hline
\end{tabular}




\section{ASSESSING ENERGY GENERATION TECHNOLOGIES WITH THE HELP OF THE DECISION SUPPORT SYSTEM EGTAV-SPS}

Issues related to the choice or development of energy generation technologies are usually handled using economic evaluation and decision justification methods which are typical in the market. These methods lack measures to make an integrated assessment of environmental factors. Energy sector is typically multidimensional and indeterminate, while the energy generation technologies in question have different quantitative and qualitative parameters. An decision support system, which is based on multiple criteria analysis methods and integrates economic, technological and environmental criteria, as well as the criteria of social issues and values, facilitates analysis of the environmental effect on the value of technologies, selection of the best technologies and analysis of the impact of criteria that determine such decisions.

A variety of multicriteria methods exists in the literature and that can be used for various purposes. The decision maker usually decides which method to be used by taking the nature of the problem into consideration. In method selection, the suitability, validity and user-friendliness of the methods are the important factors to be considered (Atici and Ulucan, 2011; Loken, 2007). A number of the recent studies deal with application of multiple criteria decision making methods in energy range. Also, multiple criteria decision making methods are suitable to tackle energy source selection problem (Wang et al., 2009; Yue and Yang, 2007).

The decision support system EGTAV-SPS for assessment of energy generation technologies has been developed based on the multiple criteria complex analysis method COPRAS (suggested by Lithuanian scientists E. K. Zavadskas and A. Kaklauskas) and the results of an expert survey (Kaklauskas and Zavadskas, 2007; Kaklauskas et al., 2007; Kaklauskas et al., 2008; Šliogerienè et al., 2009; Kanapeckienè et al., 2010). The main goal of the research is to compare, using quantitative and qualitative description, the utility of each technology in relation to each other, to rank them, to find the criteria with the biggest impact on the value of technologies and, above all, to assess the impact of the criteria of social issues and values.

\subsection{Use of the multiple criteria complex proportional assessment and utility determination method COPRAS}

This method assumes direct and proportional dependence of significance and priority by versions investigated on a system of criteria adequately describing the alternatives and on the values and weights of the criteria. A system of criteria is determined, and experts calculate the values and initial weights of criteria.

The determination of the significance and priority of alternatives is carried out in 5 stages.

Stage 1: The weighted, normalised decisionmaking matrix is formed. The purpose of this stage is to receive dimensionless weighted values from the comparative indexes. When the dimensionless values of the indexes are known, all criteria, originally having different dimensions, can be compared. The following formula is used for this purpose:

$$
d_{i j}=\frac{x_{i j} \cdot q_{i}}{\sum_{j=1}^{n} x_{i j}}, i=\overline{1, m ;} ;=\overline{1, n},
$$

where: $x_{i j}$ - the value of the $i$-th criterion in the $j$-th alternative of a solution; $m$ - the number of criteria; $n$ - the number of the alternatives compared; $q_{i}-$ weight of the $i$-th criterion.

The sum of the dimensionless weighted index value $d_{i j}$ for each criterion $x_{i}$ is always equal to the weight $q_{i}$ of this criterion: 


$$
q_{i}=\sum_{j=1}^{n} d_{i j}, i=\overline{1, m} ; j=\overline{1, n}
$$

In other words, the value of weight $q_{i}$ of the investigated criterion is proportionally distributed among all alternative versions $a_{j}$ according to their values $x_{i j}$.

Stage 2: The sums of weighted, normalised indexes describing the $j$-th version are calculated. The versions are described by minimising indexes $S_{-j}$ and maximising indexes $S_{+j}$. The lower value of minimised indexes is better and the greater value of maximised indexes is better. The sums are calculated according to the formula:

$$
\begin{aligned}
& S_{+j}=\sum_{i=1}^{m} d_{+i j} ; S_{-j}=\sum_{i=1}^{m} d_{-i j}, \\
& i=\overline{1, m} ; j=\overline{1, n} .
\end{aligned}
$$

In this case, the values $S_{+j}$ (the greater this value, the more advantages, the technology is better) and $S_{-j}$ (the lower this value, the better technology) express the degree of goals attained in each alternative technology. In any case, the sums of "pluses" $S_{+j}$ and "minuses" $S_{-j}$ of all alternatives are always, respectively, equal to all sums of the weights of maximised and minimised criteria:

$$
\begin{aligned}
& S_{+}=\sum_{j=1}^{n} S_{+j}=\sum_{i=1}^{m} \sum_{j=1}^{n} d_{+i j}, \\
& S_{-}=\sum_{j=1}^{n} S_{-j}=\sum_{i=1}^{m} \sum_{j=1}^{n} d_{-i j}, i=\overline{1, m} ; j=\overline{1, n} .
\end{aligned}
$$

Stage 3: The significance (efficiency) of the compared versions is determined by describing the characteristics of positive alternatives ("pluses") and negative alternatives ("minuses"). The relative significance $Q_{j}$ of each alternative $a_{j}$ is found according to the formula:

$$
Q_{j}=S_{+j}+\frac{S_{-\min } \cdot \sum_{j=1}^{n} S_{-j}}{S_{-j} \sum_{j=1}^{n} \frac{S_{-\min }}{S_{-j}}}, j=\overline{1, n}
$$

Stage 4: The priorities of the alternatives are determined. The greater is the $Q_{j}$ the higher is the efficiency (priority) of the energy production technology.

The analysis of the method presented makes it possible to state that it may be easily applied to evaluating projects or technologies and selecting the most efficient of them while being fully aware of the physical meaning of the process. Moreover it allows formulating a reduced criterion $Q_{j}$ which is directly proportional to the relative effect of the compared criteria values $x_{i j}$ and weights $q_{i}$ on the end result. Significance $Q_{j}$ of technology $a_{j}$ indicates the degree of effectiveness achieved - the greater is the $Q j$ the higher is the efficiency of the technology.

Stage 5: The formula used for calculating alternative $a_{j}$ utility degree $N_{j}$ is the following:

$$
N_{j}=\left(Q_{j}: Q_{\max }\right) \cdot 100 \% .
$$

The degree of technology utility is directly related to its relevant quantitative and conceptual information. For instance, if one of the technologies is described as the best in terms of creation costs, innovativeness and the effect on climate change, while the other is better in terms of production cost, competitiveness and reliability, they both may end up with the same utility degree. If certain characteristics of the investigated technology are increasing (decreasing), the utility degree is also increasing (decreasing) with them. The utility degree is determined by comparing the technologies with the most efficient one. The utility degree varies between $0 \%$ and $100 \%$. It helps to make 
both quantitative and visual assessment of the efficiency of investigated technologies.

\subsection{Building the set of criteria for the decision support system EGTV-SPS}

To formulate a real-life multiple criteria analysis problem and the algorithm for the automated decision support system, energy generation technologies employing different primary energy sources - hydro, wind and geothermal energy - have been selected. These types of renewable energy generation technologies are the most suitable for Lithuania's energy industry. The database is the basis for multi-variant designing and multiple criteria analysis of the objects. The information model presented in Figure 1 and the criteria defined in Table 1 were used to compile a set of criteria for analysis. The set of criteria has been compiled to describe each dimension of the environment. The set of quantitative criteria includes three quantitative criteria that describe economic and technical parameters of the objects. The qualitative criteria have been selected considering the research goals; they define political and environmental priorities, the preferred values and public attitudes. The dimension of social issues and values has been supplemented with the criteria which express public attitudes and public opinion about the technologies. The criteria which define the preferred values are as follows: influence on social environment (social responsibility), influence on energy culture, equal employment opportunity, public attitude toward technologies. The final set of criteria was built considering expert opinions (of experts involved in the study) on the importance of criteria in assessment of energy generation technologies. The set was used as a basis to compile an expert questionnaire with the key quantitative and qualitative criteria characterising the selected technologies. The weights of the qualitative criteria were established with the help of expert methods.

Table 2. Criteria rankings

\begin{tabular}{|c|c|c|c|}
\hline No & Criterion & Criterion weights & Criterion ranks \\
\hline 1 & Legal regulation of activities & 0,0617 & 2 \\
\hline 2 & Influence on energy security & 0,0597 & 7 \\
\hline 3 & Technology's dependability (risk of accidents) & 0,0600 & 5 \\
\hline 4 & Technology's competitiveness & 0,0596 & 8 \\
\hline 5 & Dependence on resource provision & 0,0583 & 11 \\
\hline 6 & Profitable degree & 0,0587 & 9 \\
\hline 7 & Influence on social environment & 0,0569 & 14 \\
\hline 8 & Technology's innovativeness & 0,0566 & 15 \\
\hline 9 & Influence on energy culture & 0,0565 & 16 \\
\hline 10 & Equal employment opportunities & 0,0556 & 17 \\
\hline 11 & Effect on climate change and pollution decrease & 0,0584 & 10 \\
\hline 12 & Cooperation with science establishments & 0,0571 & 13 \\
\hline 13 & $\begin{array}{l}\text { Contribution of RER (renewable energy resources) to the } \\
\text { total energy balance }\end{array}$ & 0,0578 & 12 \\
\hline 14 & Public attitude toward the technology & 0,0599 & 6 \\
\hline 15 & Company's (technology's) rated capacity & 0,0605 & 4 \\
\hline 16 & Production cost (energy price) & 0,0618 & 1 \\
\hline 17 & Technological complex value & 0,0610 & 3 \\
\hline
\end{tabular}


The study is based on a survey of six experts; they are persons knowledgeable in the field, have technical degrees and are energysector executives. The experts were interviewed between July and August 2011. They scored the criteria and ranked the criteria respectively. The criteria weights were determined in conditional units: points between 0 and 5 . The higher the weight, the more important the criterion to relevant expert and the bigger its impact on the end result of the assessment. Average values of the criteria were estimated using the expert evaluation results and determined for each expert individually. The expert ranking of the criteria related to energy generation technologies is shown in Table 2.

Expert evaluations are of stochastic nature: a new set of experts would change the criteria values, which also determine the compatibility of expert opinions (concordance coefficient) and the research reliability. This research is experimental and a more general result would require a survey of as broad circle of experts as possible. In future it would be wise to take into account the opinions of at least three expert groups when modeling decisions or selection scenarios.
The first expert group would represent analyzed sector, the second - independent national experts, while the third would represent analogous foreign experts (Diskienè et al., 2008).

\subsection{Case study: the EGTAV-SPS in assessment of energy generation technologies}

The multiple criteria analysis method COPRA and the research results were used to develop the experimental decision support system for the analysis of environmental factors of energy generation technologies EGTAV-SPS, which is intended as a tool to determine the utility degree and priority of energy generation technologies employing different energy sources, as well as the effect of environmental factors on their value.

The decision support system includes a database and a database management system, a model base and a model base management system, and a user interface (Figure 2). The model base includes a multiple criteria analysis model, a model of utility degree and priority, and a recommender model.

The model base management system lets the user choose any required model. The system

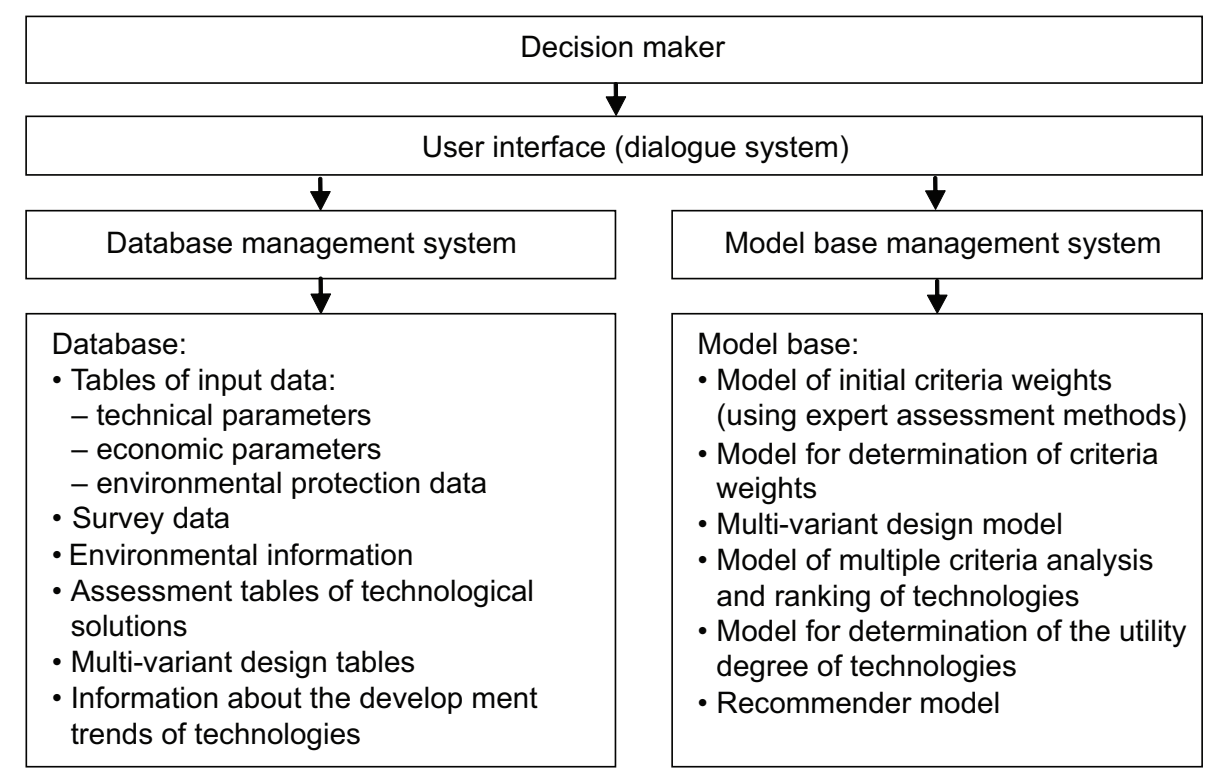

Figure 2. Components of the EGTAV-SPS 
is designed in such way that the results of calculations in one model are used as the input data in other models, which, in turn, return results which become the input data for yet other models. The decision support system EGTAV-SPS enables processing of large amounts of data and monitoring of changes of all criteria in question. The system may be supplemented with new objects and data about them. A significant advantage is that the system displays the intermediate results, which reflect the impact of each criterion on the utility and value. This research was the first time the decision support system EGTAV-SPS was used to determine the effect of environmental factors on the value of energy generation technologies with different technical and economic properties.

The decision support system EGTAV-SPS is available online at the address <http://iti. vgtu.lt/energija $>$. The opening screen is shown in Figure 3.

The user enters the expert evaluation results and the determined criteria weights in the module's table in the screen "Description of the alternatives" (see Figure 4). Then the

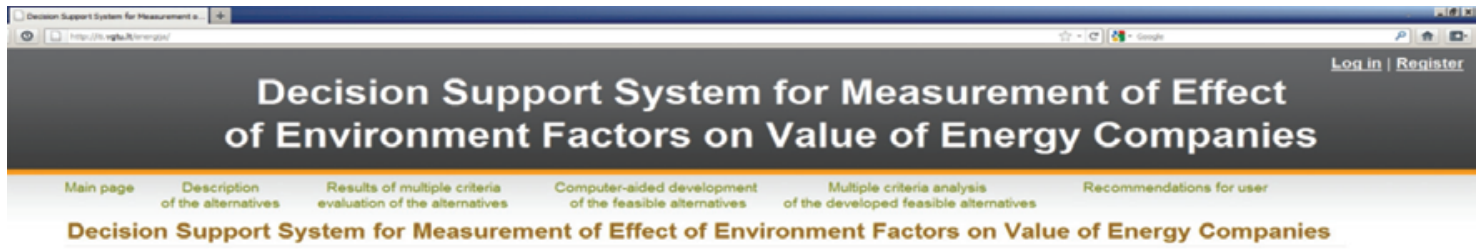

Figure 3. The opening screen of the decision support system EGTAV-SPS

Decision Support System for Measurement of Effect
of Environment Factors on Value of Energy Companies

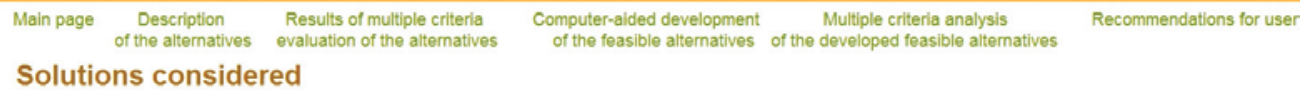

Qualitative and quantitative description of the alternatives

\begin{tabular}{|c|c|c|c|c|c|c|}
\hline \multicolumn{7}{|c|}{ Quantitative and qualitative information pertinent to alternatives } \\
\hline \multirow[t]{2}{*}{ Criteria describing the alternatives } & \multirow{2}{*}{$\sqrt{1}$} & \multirow{2}{*}{$\begin{array}{l}\text { Measuring } \\
\text { units }\end{array}$} & \multirow[t]{2}{*}{ Weight } & \multicolumn{3}{|c|}{ Compared alternatives } \\
\hline & & & & \begin{tabular}{|l} 
Kauno \\
HPP
\end{tabular} & $\begin{array}{l}\text { Geothermal } \\
\text { PP }\end{array}$ & $\begin{array}{l}\text { Wind PP } \\
\text { park }\end{array}$ \\
\hline Legal regulation of activities & +1 & points & 0,062 & 25 & 18 & 15 \\
\hline Influence on energy security & +1 & points & 0,06 & 30 & 28 & 30 \\
\hline Technology dependability (accidents risk) & + & points & 0,06 & 28 & 20 & 28 \\
\hline Technological competitiveness & + & points & 0,06 & 29 & 19 & 21 \\
\hline Dependence on resource provision & $\%$ & points & 0,058 & 6 & 21 & 9 \\
\hline Profitability degree & + & points & 0,059 & 30 & 18 & 26 \\
\hline Influence on social enviroment & + & points & 0,057 & 24 & 24 & 27 \\
\hline Technology innovation & + & points & 0,057 & 22 & 24 & 26 \\
\hline Influence on enegertic culture & + & points & 0,057 & 27 & 25 & 26 \\
\hline Equal employment opportunity & + & points & 0,056 & 17 & 15 & 21 \\
\hline Influence on climate changes, pollution decrease & $F$ & points & 0,058 & 6 & 8 & 6 \\
\hline Cooperation with science establishments & + & points & 0,057 & 20 & 26 & 28 \\
\hline $\begin{array}{l}\text { Influence of RER (renewable energy resources) in total energy } \\
\text { balanse }\end{array}$ & + & points & 0,058 & 30 & 29 & 30 \\
\hline Public attitude towards technologies & $F$ & points & 0,06 & 6 & 9 & 8 \\
\hline Company's rated capacity & + & MW & 0,061 & 100 & 35 & 35 \\
\hline Production cost price (energy price) & + & Ecnt/kwh & 0,062 & 3,2 & 5,5 & 6,9 \\
\hline Technological complex value & + & EUR & 0,061 & 52000000 & 24030000 & 31250000 \\
\hline
\end{tabular}

* The sign " $"$ indicates that a greater (less) criterion value corresponds to a greater significance for a user (stakeholders)

Figure 4. Display of the results of expert evaluation 
system automatically solves the multiple criteria problem and presents the results in model bases: determines the utility and priority of objects in question and the effect of criteria on the value of alternatives.

Use of the EGTAV-SPS is simple, but the system performs a thorough analysis and presents a lot of useful information. The system's advantage is the analysis of the weights of all criteria used in research. The weights of criteria are analysed in the module's window "Results of multiple criteria evaluation of the alternatives". A click on the value of any selected criterion in a matrix cell on the links AVG, MN displays the value of each selected criterion in percent compared to the same criterion of other objects (see Figure 5). The result also shows the increase of the percentage that would raise the value of the object in question.

\section{Results of multiple criteria evaluation of the alternatives}

Please select solution under consideration

Power plants

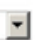

\begin{tabular}{|c|c|c|c|c|c|}
\hline \multicolumn{6}{|c|}{ Quantitative and qualitative information pertinent to alternatives } \\
\hline \multirow[t]{2}{*}{ Criteria describing the alternatives } & \multirow[t]{2}{*}{$\sqrt{\text { Measuring units }}$} & \multirow[t]{2}{*}{ Weight } & \multicolumn{3}{|c|}{ Compared alternatives } \\
\hline & & & Kauno HPP & Geothermal PP & Wind PP park \\
\hline Legal regulation of activities & + points & 0,062 & $\begin{array}{c}0,0267 \\
\text { AVG MIN } \\
\end{array}$ & $\begin{array}{c}0,0192 \\
\text { AVG MIN } \\
\end{array}$ & $\begin{array}{c}0,016 \\
\text { AVG MIN } \\
\end{array}$ \\
\hline Influence on energy security & + points & 0,06 & $\begin{array}{c}0,0205 \\
\text { AVG MIN } \\
\end{array}$ & $\begin{array}{c}0,0191 \\
\text { AVG MIN } \\
\end{array}$ & $\begin{array}{r}0,0205 \\
\text { AVG MIN } \\
\end{array}$ \\
\hline Technology dependability (accidents risk) & + points & 0,06 & $\begin{array}{c}0,0221 \\
\text { AVG MIN }\end{array}$ & $\begin{array}{c}0,0158 \\
\text { AVG MIN }\end{array}$ & $\begin{array}{l}0,0221 \\
\text { AVG MIN }\end{array}$ \\
\hline Technological competitiveness & points & 0,06 & $\begin{array}{c}0,0252 \\
\text { AVG MIN }\end{array}$ & $\begin{array}{c}0,0165 \\
\text { AVG MIN }\end{array}$ & $\begin{array}{c}0,0183 \\
\text { AVG MIN } \\
\end{array}$ \\
\hline Dependence on resource provision & points & $\overline{0,058}$ & $\begin{array}{c}0,0097 \\
\text { AVG MIN } \\
\end{array}$ & $\begin{array}{c}0,0338 \\
\text { AVG MIN } \\
\end{array}$ & $\begin{array}{c}0,0145 \\
\text { AVG MIN } \\
\end{array}$ \\
\hline Profitability degree & + points & 0,059 & $\begin{array}{r}0,0239 \\
\text { AVG MIN } \\
\end{array}$ & $\begin{array}{c}0,0144 \\
\text { AVG MIN } \\
\end{array}$ & $\begin{array}{c}0,0207 \\
\text { AVG MIN } \\
\end{array}$ \\
\hline Influence on social enviroment & + points & 0,057 & $\begin{array}{r}0,0182 \\
\text { AVG MIN } \\
\end{array}$ & $\begin{array}{r}0,0182 \\
\text { AVG MIN } \\
\end{array}$ & $\begin{array}{c}0,0205 \\
\text { AVG MIN } \\
\end{array}$ \\
\hline Technology innovation & + points & 0,057 & $\begin{array}{c}0,0174 \\
\text { AVG MIN } \\
\end{array}$ & $\begin{array}{c}0,019 \\
\text { AVG MIN } \\
\end{array}$ & $\begin{array}{c}0,0206 \\
\text { AVG MIN }\end{array}$ \\
\hline Influence on enegertic culture & points & 0,057 & $\begin{array}{c}0,0197 \\
\text { AVG MIN } \\
\end{array}$ & $\begin{array}{c}0,0183 \\
\text { AVG MIN } \\
\end{array}$ & $\begin{array}{c}0,019 \\
\text { AVG MIN } \\
\end{array}$ \\
\hline Equal employment opportunity & points & 0,056 & $\begin{array}{c}0,018 \\
\text { AVG MIN } \\
\end{array}$ & $\begin{array}{c}0,0158 \\
\text { AVG MIN } \\
\end{array}$ & $\begin{array}{c}0,0222 \\
\text { AVG MIN } \\
\end{array}$ \\
\hline Influence on climate changes, pollution decrease & points & 0,058 & $\begin{array}{c}0,0174 \\
\text { AVG MIN } \\
\end{array}$ & $\begin{array}{r}0,0232 \\
\text { AVG MIN } \\
\end{array}$ & $\begin{array}{r}0,0174 \\
\text { AVG MIN } \\
\end{array}$ \\
\hline Cooperation with science establishments & + points & 0,057 & $\begin{array}{c}0,0154 \\
\text { AVG MIN } \\
\end{array}$ & $\begin{array}{c}0,02 \\
\text { AVG MIN } \\
\end{array}$ & $\begin{array}{c}0,0216 \\
\text { AVG MIN } \\
\end{array}$ \\
\hline Influence of RER (renewable energy resources) in total energy balanse & + points & 0,058 & $\begin{array}{c}0,0196 \\
\text { AVG MIN }\end{array}$ & $\begin{array}{c}0,0189 \\
\text { AVG MIN }\end{array}$ & $\begin{array}{c}0,0196 \\
\text { AVG MIN }\end{array}$ \\
\hline Public attitude towards technologies & points & 0,06 & $\begin{array}{r}0,0157 \\
\text { AVG MIN } \\
\end{array}$ & $\begin{array}{r}0,0235 \\
\text { AVG MIN } \\
\end{array}$ & $\begin{array}{c}0,0209 \\
\text { AVG MIN } \\
\end{array}$ \\
\hline Company's rated capacity & $+M W$ & 0,061 & $\begin{array}{r}0,0359 \\
\text { AVG MIN } \\
\end{array}$ & $\begin{array}{r}0,0126 \\
\text { AVG MIN } \\
\end{array}$ & $\begin{array}{r}0,0126 \\
\text { AVG MIN } \\
\end{array}$ \\
\hline Production cost price (energy price) & $+\epsilon_{\mathrm{fcnt} / \mathrm{kwh}}$ & 0,062 & $\begin{array}{c}0,0127 \\
\text { AVG MIN } \\
\end{array}$ & $\begin{array}{r}0,0219 \\
\text { AVG MIN } \\
\end{array}$ & $\begin{array}{r}0,0274 \\
\text { AVG MIN } \\
\end{array}$ \\
\hline Technological complex value & + EUR & 0,061 & $\begin{array}{c}0,0296 \\
\text { AVG MIN }\end{array}$ & $\begin{array}{r}0,0137 \\
\text { AVG MIN } \\
\end{array}$ & $\begin{array}{c}0,0178 \\
\text { AVG MIN } \\
\end{array}$ \\
\hline The sums of weighted normalized maximizing (projects 'pluses & $\left.s^{\prime}\right)$ indices of the alte & ernative & 0,3049 & 0,2434 & 0,2789 \\
\hline The sums of weighted normalized minimizing (projects 'minuses & s') indices of the alte & ernative & 0,0428 & 0,0805 & 0,0528 \\
\hline & gnificance of the alte & ernative & 0,3597 & 0,2854 & 0,3398 \\
\hline & Priority of the alte & ernative & 1 & 3 & 2 \\
\hline Utility de & legree of the alternat & tive (\%) & $99,99 \%$ & $79,34 \%$ & $94,46 \%$ \\
\hline
\end{tabular}

*- The sign "*" indicates that a greater (less) criterion value corresponds to a greater significance for a user (stakeholders)

Figure 5. Determining the utility and priority of energy generation technologies, as well as the weights of criteria, in the EGTAV-SPS 
The same screen of the model can display the effect of environmental factors determined considering quantitative and qualitative criteria, the priority of the object in question and the utility degree.

Having processed the expert evaluation data, the system returned the following results:

1) the highest utility was attributed to Kaunas HHP, which employs hydro-technologies;

2) the second priority was attributed to the wind farm;

3) the third priority, in terms of utility, was attributed to the power plant which employs geothermal technologies.

Such results have been determined by the technology creation costs, the production cost of energy and favourable assessment of the environment. Kaunas HHP, for instance, has low production costs, received favourable assessment of the environmental aspect and is favourably received by the public. The geothermal power plan, ranked third by its utility, partly uses traditional technologies based on organic fuels (to heat the extracted geothermal water up to the required temperature). The geothermal power plant was ranked lowest because of the high production cost of energy, partial dependence on resources and less favourable public opinion of this technology.

The main advantage of the EGTAV-SPS, which distinguishes it among other decision support systems, is recommendations to user. The model analyses all alternatives using the entire set of criteria. The system automatically analyses each criterion, determines its effect, compares it among alternatives and assesses its potential to change the end result in the assessment of alternatives (see Figure 6).

The system calculates the level of influence each criterion can have on the priority and utility of an object and provides visual recommendations. For instance, the recommendations show that a $40 \%$ increase (compared to the best technology in this respect) of the reliability of technology in the geothermal power plant could improve its utility by about $2.4 \%$, while a $25 \%$ improvement of public opinion about the power plant employing wind power would raise its utility by $1.5 \%$.

The analysis of such results may be an efficient and helpful tool for comparison of energy generation technologies, for preparation of development and management decisions, and for assessment of efficiency. While changes in the effect of some criteria are hardly possible or even impossible, some of them - such as reliability, effect on the social environment and public opinion - can be changed by efforts of parties concerned.

The recommender model selects and displays three most significant criteria, which determine the utility of each alternative in question (see Figure 7). Although quantitative criteria - the rated capacity, the value of the technology and the production cost of energy have been determined as the most significant for all three technologies in question, qualitative criteria were also listed among the most important ones. For instance, based on the most significant utility-determining criteria picked by the system, the utility of the power plant employing hydro-energy depends on poor scores given to the collaboration with academic institutions and the influence on social environment (social responsibility). Higher values of these criteria would improve the object's utility of by $2.2 \%$ and $0.7 \%$ respectively. The values of the criteria can be changed without any significant investments-efforts of the staff operating the technologies would suffice.

The cost of technologies and the rated capacity are the most important criteria to the geothermal power plant and the wind farm. But the criteria "Dependence on resource provision" and "Legal regulation of activities" are also specified among the most important. While independence of resources, the prices of which are ever increasing, requires substan- 
tial investment into new technologies (the case of geothermal power plant), the settlement of legal issues is possible through efforts of executives, professional associations or public organisations (the case of wind farm).

The decision support system for assessment of energy generation technologies EGTAV-SPS facilitates the decision-maker to extract from its database versatile and thorough quantitative and qualitative information about the effect of environment and to use the model base for flexible analysis of these factors and for decision-making. The EGTAV-SPS provides logical and informative results about the utility of the technologies in question and the effect of environmental factors on their value; it also gives recommendations for each criterion and helps avoid errors and partiality. In summary, the developed decision support system EGTAV-SPS enables unbiased results, which can be used in assessment of a range of energy generation technologies, their utility and the efficiency of their environment; in other analyses as well.

\begin{tabular}{|c|c|c|c|c|c|c|}
\hline \multicolumn{7}{|c|}{ Recommendations for user } \\
\hline \multicolumn{7}{|l|}{ Please select solution under consideration } \\
\hline \multicolumn{6}{|c|}{ Power plants } & \multirow{2}{*}{$\sqsupset$} \\
\hline \multirow{2}{*}{\multicolumn{7}{|c|}{ Qualitative and quantitative description of the alternatives }} \\
\hline \multicolumn{4}{|c|}{ Quantitative and qualitative information pertinent to alternatives } & & & \\
\hline \multirow{2}{*}{\multicolumn{2}{|c|}{ Criteria describing the alternatives }} & \multirow[t]{2}{*}{$\begin{array}{l}\text { Measuring } \\
\text { units }\end{array}$} & \multirow[t]{2}{*}{ Weight } & \multicolumn{3}{|c|}{$\begin{array}{l}\text { - Compared alternatives } \\
\text { - Possible improvement of the analysed criterion in \% } \\
\text { - Possible increase of the value of the alternative in \% through increased } \\
\text { value of the aforementioned criterion }\end{array}$} \\
\hline & & & & Kauno HPP & Geothermal PP & Wind PP park \\
\hline Legal regulation of activities & + & points & 0,062 & $\begin{array}{l}25 \\
(0 \%)(0 \%)\end{array}$ & $\begin{array}{l}18 \\
(38,89 \%)(2,404 \%)\end{array}$ & $\begin{array}{l}15 \\
(66,67 \%)(4,121 \%)\end{array}$ \\
\hline Influence on energy security & + & points & 0,06 & $\begin{array}{l}30 \\
(0 \%)(0 \%)\end{array}$ & 28 (7,14\%)(0,427\%) & $\begin{array}{l}30 \\
(0 \%)(0 \%)\end{array}$ \\
\hline Technology dependability (accidents risk) & + & points & 0,06 & $\begin{array}{l}28 \\
(0 \%)(0 \%)\end{array}$ & $\begin{array}{l}20 \\
(40 \%)(2,393 \%)\end{array}$ & $\begin{array}{l}28 \\
(0 \%)(0 \%)\end{array}$ \\
\hline Technological competitiveness & + & points & 0,06 & $\begin{array}{l}29 \\
(0 \%)(0 \%)\end{array}$ & $\begin{array}{l}19 \\
(52,63 \%)(3,148 \%)\end{array}$ & $\begin{array}{l}21 \\
(38,1 \%)(2,279 \%)\end{array}$ \\
\hline Dependence on resource provision & 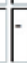 & points & 0,058 & $\begin{array}{l}6 \\
(0 \%)(0 \%)\end{array}$ & $\begin{array}{l}21 \\
(71,43 \%)(4,13 \%)\end{array}$ & $(33,33 \%)(1,928 \%)$ \\
\hline Profitability degree & + & points & 0,059 & $\begin{array}{l}30 \\
(0 \%)(0 \%)\end{array}$ & $\begin{array}{l}18 \\
(66,67 \%)(3,922 \%)\end{array}$ & $\begin{array}{l}26 \\
(15,38 \%)(0,905 \%)\end{array}$ \\
\hline Influence on social enviroment & + & points & 0,057 & $\begin{array}{l}24 \\
(12,5 \%)(0,71 \%)\end{array}$ & $\begin{array}{l}24 \\
(12,5 \%)(0,71 \%)\end{array}$ & $\begin{array}{l}27 \\
(0 \%)(0 \%)\end{array}$ \\
\hline Technology innovation & + & points & 0,057 & $\begin{array}{l}22 \\
(18,18 \%)(1,033 \%)\end{array}$ & $\begin{array}{l}24 \\
(8,33 \%)(0,474 \%)\end{array}$ & $\begin{array}{l}26 \\
(0 \%)(0 \%)\end{array}$ \\
\hline Influence on enegertic culture & + & points & 0,057 & $\begin{array}{l}27 \\
(0 \%)(0 \%)\end{array}$ & $\begin{array}{l}25 \\
(8 \%)(0,455 \%)\end{array}$ & $\begin{array}{l}26 \\
(3,85 \%)(0,219 \%)\end{array}$ \\
\hline Equal employment opportunity & + & points & 0,056 & $\begin{array}{l}17 \\
(23,53 \%)(1,314 \%)\end{array}$ & $\begin{array}{l}15 \\
(40 \%)(2,233 \%)\end{array}$ & $\begin{array}{l}21 \\
(0 \%)(0 \%)\end{array}$ \\
\hline $\begin{array}{l}\text { Influence on climate changes, pollution } \\
\text { decrease }\end{array}$ & & points & 0,058 & $\begin{array}{l}6 \\
(0 \%)(0 \%)\end{array}$ & 8 & $\begin{array}{l}6 \\
(0 \%)(0 \%)\end{array}$ \\
\hline Cooperation with science establishments & + & points & 0,057 & $\begin{array}{l}20 \\
(40 \%)(2,273 \%)\end{array}$ & 26 (7,69\%)(0,437\%) & $\begin{array}{l}28 \\
(0 \%)(0 \%)\end{array}$ \\
\hline $\begin{array}{l}\text { Influence of RER (renewable energy } \\
\text { resources) in total energy balanse }\end{array}$ & + & points & 0,058 & $\begin{array}{l}30 \\
(0 \%)(0 \%)\end{array}$ & $\begin{array}{l}29 \\
(3,45 \%)(0,199 \%)\end{array}$ & $\begin{array}{l}30 \\
(0 \%)(0 \%)\end{array}$ \\
\hline Public attitude towards technologies & & points & 0,06 & $\begin{array}{l}6 \\
(0 \%)(0 \%)\end{array}$ & $\begin{array}{l}9 \\
(33,33 \%)(1,994 \%)\end{array}$ & $\begin{array}{l}8 \\
(25 \%)(1,496 \%)\end{array}$ \\
\hline Company's rated capacity & + & MW & 0,061 & $\begin{array}{l}100 \\
(0 \%)(0 \%)\end{array}$ & $\begin{array}{l}35 \\
(185,71 \%)(11,295 \%)\end{array}$ & $\begin{array}{l}35 \\
(185,71 \%)(11,295 \%)\end{array}$ \\
\hline Production cost price (energy price) & + & Ecnt/kwh & 0,062 & $\begin{array}{l}3,2 \\
(115,62 \%)(7,147 \%)\end{array}$ & $\begin{array}{l}5,5 \\
(25,45 \%)(1,573 \%)\end{array}$ & $\begin{array}{l}6,9 \\
(0 \%)(0 \%)\end{array}$ \\
\hline Technological complex value & + & EUR & 0,061 & $\begin{array}{l}52000000 \\
(0 \%)(0 \%)\end{array}$ & $\begin{array}{l}24030000 \\
(116,4 \%)(7,079 \%)\end{array}$ & $\begin{array}{l}31250000 \\
(66,4 \%)(4,038 \%)\end{array}$ \\
\hline
\end{tabular}

*- The sign "*" indicates that a greater (less) criterion value corresponds to a greater signific ance for a user (stakeholders)

Figure 6. The recommender module 
TOP 3 object criterions that have greatest influence on ranking

\begin{tabular}{|r|l|l|l|}
\hline Position & $\begin{array}{l}\text { Criteria describing the } \\
\text { alternative }\end{array}$ & $\begin{array}{l}\text { Possible improvement of the } \\
\text { analysed criterion in \% }\end{array}$ & $\begin{array}{l}\text { Possible increase of the value of the alternative in \% through } \\
\text { increased value of the aforementioned criterion }\end{array}$ \\
\hline 1 & $\begin{array}{l}\text { Production cost price } \\
\text { (energy price) }\end{array}$ & $116 \%$ \\
\hline 2 & $\begin{array}{l}\text { Cooperation with science } \\
\text { establishments }\end{array}$ & $40 \%$ & \\
\hline 3 & $\begin{array}{l}\text { Influence on social } \\
\text { enviroment }\end{array}$ & $12 \%$ & $1 \%$ \\
\hline
\end{tabular}

\begin{tabular}{|c|c|c|c|}
\hline \multicolumn{4}{|c|}{ Geothermal PP } \\
\hline Position & $\begin{array}{l}\text { Criteria describing the } \\
\text { alternative }\end{array}$ & $\begin{array}{l}\text { Possible improvement of the } \\
\text { analysed criterion in \% }\end{array}$ & $\begin{array}{l}\text { Possible increase of the value of the alternative in \% through } \\
\text { increased value of the aforementioned criterion }\end{array}$ \\
\hline$\overline{1}$ & $\begin{array}{l}\text { Company's rated } \\
\text { capacity }\end{array}$ & $186 \%$ & $11 \%$ \\
\hline$\overline{2}$ & $\begin{array}{l}\text { Technological complex } \\
\text { value }\end{array}$ & $116 \%$ & $7 \%$ \\
\hline & \begin{tabular}{|l} 
Dependence on \\
resource provision
\end{tabular} & $71 \%$ & $4 \%$ \\
\hline
\end{tabular}

\begin{tabular}{|r|l|l|l|}
\hline \multicolumn{2}{|c|}{ Wind PP park } \\
\hline Position & $\begin{array}{l}\text { Criteria describing the } \\
\text { alternative }\end{array}$ & $\begin{array}{l}\text { Possible improvement of the } \\
\text { analysed criterion in \% }\end{array}$ & $\begin{array}{l}\text { Possible increase of the value of the alternative in \% through } \\
\text { increased value of the aforementioned criterion }\end{array}$ \\
\hline 1 & $\begin{array}{l}\text { lempany's rated } \\
\text { capacity }\end{array}$ & $186 \%$ \\
\hline 2 & \begin{tabular}{ll|l} 
Legal regulation of \\
activities
\end{tabular} & $67 \%$ \\
\hline 3 & $\begin{array}{llll}\text { Technological complex } \\
\text { value }\end{array}$ & $66 \%$ & $4 \%$ \\
\hline
\end{tabular}

Figure 7. The most significant criteria specified by the recommender module

The EGTAV-SPS is an experimental system, but at this stage it can already be used as an additional tool in a range of studies or as a controlling tool to verify the results of other investigations. Improvements of the system could make it useful for the analysis of performance, identification of crucial values of environmental factors and as an auxiliary tool to plan the course of actions, choose development scenarios and compare technologies. The system may also include the model of market value determination, but assessment of energy generation technologies from the market perspective would require market data and other types of studies.

\section{CONCLUSIONS}

When it comes to the analysis of the development trends of energy generation technologies, selection of technological alternatives or measurement of the utility and efficiency of individual energy generation technologies, the main course of research is selection of criteria and building their system which can be universally applied across the technologies. It is important to determine the relationship among criteria describing various aspects, to choose proper criteria important to the analysis and perform rather broad studies, which enable proper assessment of the weights. Such actions would help to develop more universal 
decision support systems for the analysis of this industry and to make their use increasingly popular. Integrated assessment of technical, economic and environmental aspects, as well as the dimension of social issues and values is possible by choosing and using appropriate multiple analysis methods, such as COPRAS (the multiple criteria complex utility degree and market value determination method) used in this research. The method was used to process the values of the environmental factors of energy objects chosen for this analysis, to determine criteria weights and to compile the set of criteria, which can be used in analysis of other equivalent objects.

The expert assessment of the effect of environmental factors on the value of energy generation technologies has shown that such technologies must be analysed from a much broader perspective than just their technical or economic properties. Because the goal of creation and implementation of energy generation technologies is satisfaction of public needs, their assessment must also consider the feedback, which is expressed through the environmental protection aspect and the dimension of social issues and values. The research suggests that criteria of social issues and values play a role in the utility of objects, as well as in their value. The criteria of values may force modification of plans of action and set new guidelines of communication with the public. Assessment of the dimension of social issues and values enables finding the relationship linking technological solutions, economic benefits and the general public.

On a broader scale, the fact that energy generation and supply is "business without borders" should also be considered. In integration attempts, the choice of technologies is not an insignificant factor. Regard for public attitudes and the cultural level of neighbouring countries is the foundation of future collaboration and partnership. The models dealing with preparation of decisions on technological development must analyse the dimension of values - it is the future norm.

To sum up, assessment of the outcomes related to the role played in markets by economic, technological and environmental dimensions, as well as the dimension of social issues and values, helps make a decision on the utility and acceptability of selected technologies and on their suitability to the public; in this context, it also determines the choice of technologies which are more efficient, more appealing to the public, and have better quality in terms of environmental protection.

\section{ACKNOWLEDGEMENTS}

This research has been performed and the materials for publication prepared using the grant awarded by the Research Council of Lithuania in line with the promotion measure for the mobility of scientists and other researchers and scientific research by students (VP1-3.1- MM-01). We are also grateful to the University of Bologna, which contributed to the research and this publication.

\section{REFERENCES}

Atici, K. B. and Ulucan, A. (2011) A multicriteria energy decision support system, Technological and Economic Development of Economy, 17(2), pp. 219-245 http://dx.doi.org/10.3846/2029491 3.2011 .580563

Augutis, J., Krikštolaitis, R., Pečiulytè, S. and Konstantinavičiūtè, I. (2011) Sustainable dvelopment and energy security level after Ignalina NPP shutdown, Technological and Economic Development of Economy, 17(1), pp. 5-21. http://dx.doi.org/10.3846/13928619.2011 .553930

Becker, H. A. (2001) Social impact assessment, European Journal of Operational Research, 128, pp. 311-321. http://dx.doi.org/10.1016/S03772217(00)00074-6

Bojnec, Š. and Papler, D. (2011) Economic efficiency, energy consumption and sustainable development, Journal of Business Economics and 
Management, 12(2), pp. 353-374. http://dx.doi. org/10.3846/16111699.2011.573278

Carlsson-Kanyamaa, A., Juliá, I. R. and Röhr, U. (2010) Unequal representation of women and men in energy company boards and management groups: Are there implications for mitigation? Energy Policy, 38(8), pp. 4737-4740. http://dx.doi.org/10.1016/j.enpol.2010.03.072

Cappers, P. and Goldman, Ch. (2010) Financial impact of energy efficiency under a federal combined efficiency and renewable electricity standard: Case study of a Kansas "super-utility”, Energy Policy, 38(8), pp. 3998-4010. http://dx.doi.org/10.1016/j.enpol.2010.03.024

Diskienè, D., Galinienè, B. and Marčinskas, A. (2008) Strategic management model for economic development, Technological and Economic Development of Economy, 14(3), pp. 375-387. http:// dx.doi.org/10.3846/1392-8619.2008.14.375-387

International Atomic Energy Agency (IAEA), United Nations Department of Economic and Social Affairs (UNDESA), International Energy Agency (IEA), Eurostat, European Environment Agency (EEA) (2005) Energy Indicators for Sustainable Development: Methodologies and Guidelines, International Atomic Energy Agency (IAEA), Vienna.

Jansen, J. C. and Seebregts, A. J. (2010) Long-term energy services security: What is it and how can it be measured and valued?, Energy Policy, 38(4), pp. 1654-1664.

http://dx.doi.org/10.1016/j.enpol.2009.02.047

Ferraro, F., Pfeffer, J. and Sutton, R. I. (2009) How and why theories matter: A comment of Felin and Foss, Organization Science, 20(3), pp. 669675. http://dx.doi.org/10.1287/orsc.1090.0432

Gallego Carrera, D. and Mack, A. (2010) Sustainability assessment of energy technologies via social indicators: Results of a survey among European energy experts, Energy policy, 38(2), pp. 1030-1039.

http://dx.doi.org/10.1016/j.enpol.2009.10.055

Huse, M., Tacheva Nielsen, S. and Hagen, I. M. (2009) Women and employee-elected board members, and their contributions to board control tasks, Journal of Business Ethics, 89, pp. 581-597.

http://dx.doi.org/10.1007/s10551-008-0018-4

Husted, B. W. and Salazar, J. J. (2006) Taking Friedman seriously: maximizing profits and social performance, Journal of Manage- ment Studies, 43(1), pp. 75-91. http://dx.doi. org/10.1111/j.1467-6486.2006.00583.x

Ghoshal, S. (2005) Bad management theories are destroying good management practices, Academy of Management Learning and Education, 4(1), pp. 75-91.

http://dx.doi.org/10.5465/AMLE.2005.16132558

Grunwald, A. (2011) Energy futures: Diversity and the need for assessment, Futures of Evolutionary Psychology, 43(8), pp. 820-830.

Kaklauskas, A. and Zavadskas, E. K. (2007) Decision support system for innovation with a special emphasis on pollution, International Journal of Environment and Pollution, 30(3-4), pp. 518-528. http://dx.doi.org/10.1504/IJEP.2007.014826

Kaklauskas, A., Zavadskas, E. K. and Trinkūnas, V. (2007) A multiple criteria decision support online system for construction, Journal of Engineering Applications of Artificial Intelligence, 20, pp. 163-175. http://dx.doi.org/10.1016/j.engappai.2006.06.009

Kaklauskas, A., Zavadskas, E. K. and Galinienè, B. (2008) A building's construction project knowledge-based decision support system, International Journal of Environment and Pollution, 35(2/3/4), pp. 237-249.

Kanapeckienè, L., Kaklauskas, A., Zavadskas, E. K. and Seniut, M. (2010) Integrated knowledge management model and system for construction projects, Journal of Engineering Applications of Artificial Intelligence, 23, pp. 12001215. http://dx.doi.org/10.1016/j.engappai.2010.01.030

Kemmler, A. and Spreng, D. (2007) Energy indicators for tracking sustainability in developing countries, Energy Policy, 35(4), pp. 2466-2480. http://dx.doi.org/10.1016/j.enpol.2006.09.006

Kruyt, B., Vuuren, D. P., Vries, H. J. M. and Groenenberg, H. (2009) Indicators for energy security, Energy Policy, 37(6), pp. 2166-2181. http://dx.doi.org/10.1016/j.enpol.2009.02.006

Leiserowitz, A., Kates, R., and Parris, T. (2006) Sustainability values, attitudes and behaviors: A review of multi-national and global trends, Annual Review of Environment and Resources, 31(1), pp. 413-444. http://dx.doi.org/10.1146/ annurev.energy.31.102505.133552

Löschel, A., Moslener, U. and Rübbelke, D. T. G. (2010) Indicators of energy security in in- 
dustrialised countries, Energy Policy, 38(4), pp. 1665-1671.

http://dx.doi.org/10.1016/j.enpol.2009.03.061

Loken, E. (2007) Use of multicriteria decision analysis methods for energy planning problems, Renewable and Sustainable Energy Reviews, 11(7), pp. 1584-1595.

http://dx.doi.org/10.1016/j.rser.2005.11.005

Loomis, J. B. and Rosenberger, R. S. (2006) Reducing barriers in future benefit transfers: Needed improvements in primary study design and reporting, Ecological Economics, 60(2), pp. 343-350.

http://dx.doi.org/10.1016/j.ecolecon.2006.05.006

Matson, R. J. and Carasso, M. (1999) Sustainability, energy technologies and ethics, Renewable Energy, 16(4), pp. 1200-1204. http://dx.doi. org/10.1016/S0960-1481(98)00482-0

Melnov, S. B. and Sarana, J.V. (2010) Ethical aspects of Chernobyl disaster consequences. Environmental ethics: The power of ethics for sustainable development. Collective monograph. Mykolas Romeris University. Vilnius 2010, pp. 329-345. ISBN 978-9955-19-199-5.

Moeller, C. (1988) Ethics training. In: Kellar, E. K. (eds.), Ethical insight, ethical action: Perspectives for the local government manager, International City/County Management Association, pp. 116-130.

Musango, J. K. and Brent, A. C. (2011) A conceptual framework for energy technology sustainability assessment, Energy for Sustainable Development, 15(1), pp. 84-91.

http://dx.doi.org/10.1016/j.esd.2010.10.005

NEEDS, New Energy Externalities Development for Sustainability. Environmental, economic and social criteria and indicators for sustainability assessment of energy technologies (2007) [Online] Available at: Palm, J. and Thollander, P. (2010) An interdisciplinary perspective on industrial energy efficiency, Applied Energy, 87(10), pp. 3255-3261.

Rayner, S. (2010) Trust and the transformation of energy systems, Energy Policy, 38(6), pp. 2617-2623.

http://dx.doi.org/10.1016/j.enpol.2009.05.035

Rogoža, A., Čiuprinskas, K. and Šiupšinskas, G. (2006) The optimisation of energy systems by using 3e factor: The case studies, Journal of Civil Engineering and Management, 12(1), pp. 63-68.
Sychev, A. (2010) Ethical dimensions of sustainability. Environmental ethics: the power of ethics for sustainable development. Collective monograph. Mykolas Romeris University. Vilnius 2010, pp. 45-70. ISBN 978-9955-19-199-5.

Schwartz, S. H. (1996) Value priorities and behavior: Applying a theory of integrated value systems. In: Seligman, C., Olson, J. M. and Zanna, M. P. (Eds.). The Psychology of values: The Ontario symposium, 8, pp. 1-24. Hillsdale, NJ: Erlbaum.

Schweizer-Ries, P. (2008) Energy sustainable communities: Environmental psychological investigations, Energy Policy, 36(11), pp. 4126-4135. http://dx.doi.org/10.1016/j.enpol.2008.06.021

Shepherd, D. A., Kuskova, V. and Patzelt, H. (2009) Measuring the values that underlie sustainable development: The development of a valid scale, Journal of Economic Psychology, 30(2), pp. 246-256.

http://dx.doi.org/10.1016/j.joep.2008.08.003

Sims, S., Dent, P. and Oskrochi, R. (2008) Modelling the impact of wind farms on house prices in the UK, International Journal of Strategic Property Management, 12(4), pp. 251-269. http:// dx.doi.org/10.3846/1648-715X.2008.12.251-269

Smith, E. R. N. (2004) Public reaction to energy, overview, Encyclopedia of Energy, 5(6), pp. 169-179.

Sovacool, B. K. and Mukherjee, I. (2011) Conceptualizing and measuring energy security: A synthesized approach, Energy, 36(8), pp. 5343-5355. http://dx.doi.org/10.1016/j.energy.2011.06.043

Stephenson, J., Barton, B., Carrington, G., Gnoth, D., Lawson, R. and Thorsnes, P. (2010) Energy cultures: A framework for understanding energy behaviours, Energy Policy, 38(10), pp. 6120-6129.

http://dx.doi.org/10.1016/j.enpol.2010.05.069

Šliogerienè, J., Kaklauskas, A., Zavadskas, E. K., Bivainis, J. and Seniut, M. (2009) Environment factors of energy companies and their effect on value: analysis model and applied methods, Technological and Economic Development of Economy, 15(3), pp. 490-521. http://dx.doi. org/10.3846/1392-8619.2009.15.490-521

Štreimikienè, D., Čiegis, R. and Grundey, D. (2007) Energy indicators for sustainable development in Baltic States, Renewable and Sustainable Energy Reviews, 11(5), pp. 877-893. http://dx.doi.org/10.1016/j.rser.2005.06.004 
Štreimikienè, D., Simanavičienè, Z. and Kovaliov, R. (2009) Corporate social responsibility for implementation of sustainable energy development in Baltic States, Renewable and Sustainable Energy Reviews, 13(4), pp. 813-824. http:// dx.doi.org/10.1016/j.rser.2008.01.007

Teravainen, T., Lehtonen, M. and Martiskainen, M. (2011) Climate change, energy security, and risk - debating nuclear new build in Finland, France and the UK, Energy Policy, 39(6), pp. 3434-3442.

http://dx.doi.org/10.1016/j.enpol.2011.03.041

UN (2000) The United Nations Millennium Declaration. General Assembly resolution 55/2 of 8 September 2000. New York: United Nations. Available at: <http://www.un.org/millennium/ declaration $>$.

Vallance, S., Perkins, H. C., Jennifer E. and Dixon, J. E. (2011) What is social sustainability? A clarification of concepts, Geoforum, 42, pp. 342-348. http://dx.doi.org/10.1016/j.geoforum.2011.01.002
Vera, I. and Langlois, L. (2007) Energy indicators for sustainable development, Energy, 32(6), pp. 875-882.

http://dx.doi.org/10.1016/j.energy.2006.08.006

Wang, J. J., Jing, Y. Y., Zhang, C. F. and Zhao, J. H. (2009) Review on multi-criteria decision analysis aid in sustainable energy decision-making, Renewable and Sustainable Energy Review, 13(9), pp. 2263-2278.

http://dx.doi.org/10.1016/j.rser.2009.06.021

Williams, Jr. R. M. (1979) Change and stability in values and values systems: A sociological perspective. In: Rokeach, M. (eds.), Understanding Human Values, pp. 15-46. New York: The Free Press.

Yue, C-D. and Yang, G. G-L. (2007) Decision support system for exploiting local renewable energy sources: A case study of the Chigu area of southwestern Taiwan, Energy Policy, 35(1), pp. 383-394.

http://dx.doi.org/10.1016/j.enpol.2005.11.035 